\title{
Chinese Historic Buildings Fire Safety and Countermeasure
}

\author{
An Zhengyang \\ Trainming dept \\ Kunming Fire Service Training School \\ Kunming, China \\ anzhengyang2005@sina.com
}

\author{
Wang Yuanyuan \\ Training dept \\ Kunming Fire Service Training School \\ Kunming, China \\ 1009541492@qq.com
}

\begin{abstract}
The cultural relic buildings are both valuable cultural heritage left by ancestor and mark of the cultural development during that time. On the basis of the research and analysis of the present situation and existing problems about fire safety management of the historic buildings in China, corresponding prevention and control strategies were provided.
\end{abstract}

Keywords-Historic building; Fire safety management; Prevention and control strategie

\section{INTRODUCTION}

It is said that Shanxi xi'an has five thousand years' culture, Shanxi has that of three thousand years, Beijing has that of one thousand years, while Shanghai has one only one hundred years. The reason for this is that the local historic buildings reflect the continuity of the culture development and illustrate the source and current of history vividly[1]. The cultural relic buildings are both valuable cultural heritage left by ancestor and mark of the cultural development during that time, not only the pride of a nation and her people but also cultural treasure of whole mankind[2]. Since the cultural relic buildings are unrenewable, more attention should be paid on their protection. Through the research and analysis of the present situation and existing problems about fire safety management of the historic buildings in China, corresponding prevention and control strategies were provided in this paper.

The Present situation of fire safety management of historic building in China

Wherever Times is specified, Times Roman or Times New Roman may be used. If neither is available on your word processor, please use the font closest in appearance to Times[3]. Avoid using bit-mapped fonts if possible. True-Type 1 or Open Type fonts are preferred. Please embed symbol fonts, as well, for math, etc.

\section{A. Unclear Responsibility of Fire Safety Management due to UnclearProperty Right of Historic Building}

In some places, affected by some reasons of history, economic development and confusion and so on, problems such as unclear responsibility of fire safety management and unclear property right of historic building exist[4].

Without any corresponding protection, some historic buildings are occupied by local institutes and citizens as common house, teaching room or office. Hence, risk of fire safety exists long-term. With the acceleration of urbanization process and the increase of urban population continuously, due to the users of these historic buildings don't have any property right of buildings, fire protection responsibility is unclear and rampant occurrences of congestion, destruction, dirt and disorder, widespread illegal structures occur, which makes the situation of fire safety worse and worse[5].

\section{B. New Risk of Fire Protection from Development and Utilization of Tourism Resource about CulturalRelic Building}

Under the thought of "Those living on a mountain live off the mountain, those living near the water live off the water", the managers and nearby residents of cultural relic buildings pursue the economic benefits one-sidedly and ignore the fire safety management during the development and utilization of cultural relic buildings by running hotels, guest rooms and restaurants inside these buildings illegally and rule-breaking, which brings a large of fire protection risks such as increase of inner fire source, bad management and illegal electric circuit. Furthermore, the guest amounts is big and incense burning has never stop in historic building, so these human factors bring many new problems to the fire safety management of historic buildings. It is showed in table I that the main causes of fire in cultural relic building[6].

TABLE I. THE MAIN CAUSES OF FIRE IN CULTURAL RELIC BUILDING

\begin{tabular}{ccc}
\hline Example & the main causes of fire & Rate $(\%)$ \\
\hline Shizang temple (Hainan) & Careless use of fire & 40 \\
Hu guo temple (Beijing) & causes from electrical device & 20 \\
Pu you temple (Beijing) & Thunder strike & 15 \\
Qiong zhu temple (Yunnan) & religious activities & 10 \\
\hline
\end{tabular}

\section{Weak Facilities and Insufficient Power of Fire}

\section{Protection}

Because of relatively backward economy and insufficient investment of special fire protection fund, fire protection facilities in some cultural relic buildings are weak and the present fire extinguishing equipments are backward and insufficient. There is neither volunteer fire company nor public security fire company in some institutes of cultural relic building a, which makes serious shortage of fire extinguishing power and fail to reach the requirement of fire safety management about cultural relic building. On the other side, the owner and manager don't have clear responsibilities for the fire safety management 
of cultural relic building and tend to attach less responsibility to investment in fire safety management, which leads to the failed implementation of necessary fire facilities such as fire pump, automatic alarm system and automatic fire extinguishing system[7].

\section{Imperfect Law and Regulationsystem about Fire \\ Protection of Historic Building and Incomplete \\ Implementation of Fire Safety Management}

By now, the fire safety management of historic building mainly follow Fire Protection Management Regulations of Historic Building, Law of Cultural Relics and Law of Fire Protection and so on. However, these laws and regulation have certain historical limitations. For example, several factors, such as enactment of responsiblity, assignment of application scope, distribution of fire equippments and construction of basic facilities of fire water supply, fire extinguishing installation and automatic alarm system and so on, are hard to satisfy the necessary of practical fire protection work, and the fire sfaety management measures faile to ahieve the requirement of fire safety management of cultural relic buildings[8]. It is showed in table II that The related laws and regulations of the fire safety management in historic building.

TABLE II. THE LAWS AND REGULATIONS ABOUT HISTORIC BUILDING

\begin{tabular}{|c|c|c|}
\hline Example & Release form & Effective time \\
\hline $\begin{array}{l}\text { Law on the protection of } \\
\text { cultural relics }\end{array}$ & $\begin{array}{l}\text { Eighty-fourth order of } \\
\text { President of the people's } \\
\text { Republic }\end{array}$ & $2007-12-29$ \\
\hline $\begin{array}{l}\text { Regulations for the } \\
\text { protection of cultural } \\
\text { relics }\end{array}$ & $\begin{array}{l}\text { Decree of the State } \\
\text { Council order } 377^{\text {th }}\end{array}$ & 2003-05-18 \\
\hline $\begin{array}{c}\text { Fire Regulations of the } \\
\text { Peoples Republic of } \\
\text { China }\end{array}$ & $\begin{array}{l}\text { sixth order of President } \\
\text { of the people's Republic }\end{array}$ & 2009-05-01 \\
\hline $\begin{array}{c}\text { Fire Regulations of the } \\
\text { Famous Historical and } \\
\text { Cultural Cities }\end{array}$ & $\begin{array}{l}\text { Decree of the State } \\
\text { Council order } 524 \text { th }\end{array}$ & 2008-07-01 \\
\hline $\begin{array}{l}\text { The protection } \\
\text { management rules of the } \\
\text { cultural relics }\end{array}$ & religious activities & 1984-02-28 \\
\hline
\end{tabular}

\section{E. Strengthen the leading construction to clear responsibility of fire safety management of cultural relic building}

During the fire safety management of historic building, all levels of people's governments should play leadership function fully and set up leading construction commanded by government chief leaders to hold special conference[9]. Besides, chief leader should frequently lead inspection of fire safety at institutes or places about cultural relic buildings in person, analyze and research seriously those problems and shortcomings in fire safety management about cultural relic building, coordinate and solve actively those big problems found in work, offer feasible and practical working plan, adopt effective measures and strengthen comprehensively the supervision of fire safety management about cultural relic building.

According to their own properties, all institutes about cultural relic building should set up and perfect preparedness of fire protection and fire extinguishing, strengthen daily patrol and fire safety management, realize the responsibility systems of fire safety and post fire protection by degrees, and ensure all measures to make real effect[10].

All levels public security and fire supervision departments should behave well as government staff officer actively, positively supervise all levels governments and corresponding functional departments to work independently, accomplish fire safety management work about historic building coordinately and propel the all-round development of fire safety management work about historic building through implement responsibility systems. Additionally, social managing institutes, managers and citizens are responsible to take part in the maintenance of the fire safety and utilization of fire safety facilities.

\section{F. Deepen Special Management of Cultural Relic Building to Eliminate Risk of Fire}

During the special management of cultural relic building, all levels supervisors should organize carefully, act quickly and design effective corresponding measures. Liquefied petroleum gas and open fire are forbidden strictly to be utilized inside cultural historic building. In case of circuit's laying, electric wire should be laid into metal tube instead of onto combustible components such as beam and column. In case of burning incense and ignition lamp and candle, fire should be offered at safety place and location with special personal supervision. Special person should be assigned to patrol "The Forever Lamp" in historic building at night and extinguish the incense and candle before leaving.

\section{G. Strengthen the Investment for the Protection of Cultural Relic Building to Improve Fire Protection Ability}

If cultural relic building is located in urban, public fire basic facilities should be perfected according to the practical necessary of fire water supply amount through adding fire water supply pip network or numbers of hydrant nearby cultural relic building. If the cultural relic is located in remote mountain area, there should be enough fire pools or water vats, as well as some necessary fire equipments which are complete and good to use. Systems such as automatic alarm, fire protection detection and fire extinguishing should be installed at important sections to fulfill all weather, all directional and multi-angle timely discovery and effective extinguishing. Cultural relic building should be equipped with lightning protection facilities such as lightning rod, wire, cage and belt and so on. If the condition allows, certain number fire extinguishing equipments of micro fire vehicle, motor pump and water bag and squirt are required according to the properties of old building and water source. In developed areas, pulse squirt can be equipped and helicopter can be utilized to combine sky and ground protection. 


\section{H. Strengthen the Propaganda and Education of Fire \\ Safety Management about Cultural Relic Building to \\ Form Comprehensive Management}

The fire prevention awareness can be improved by strengthen the propaganda and education of fire protection to the tourisms, staff and citizens to master basic fire extinguishing knowledge. The fire training should be strengthened in the staff of the institute to improve the fire prevention awareness continuously.

Public security and fire department should cooperate with departments of cultural relic, religion and tourism positively and overall play functions of supervision and instruction. Illegal and rules-breaking activities, for example, not improving fire safety measures, should be punished seriously and strictly. The department should instruct the institute about cultural relic building to firmly establish the fire prevention awareness, carry out fire safety responsibility system, strengthened daily fire safety management and eliminate fire risk timely. Those fire extinguishing equipments and facilities should be ensured in good conditions if necessary. Preparedness of fire protection and fire extinguishing should be set up, perfected and practiced properly to improve the fire prevention awareness and abilities of self-protection and self-rescue.

Institute of historic building itself should conduct well work of self-check, self-repair and fire risk correction. As for national key protected institute of historic building, volunteer fire company should be organized by the institute's own staff and the staff from the cultural relic protection institute. If there is a fire, under the close cooperation and standard operation, the fire can be controlled or extinguished before the reaching of other fire extinguishing power.

\section{Perfect the Law Construction about the Old Building Remedy to Provide Legal Safeguard}

By now, there is no law really suitable for the current fire protection management of the old building remedy in China. Therefore, it is necessary to carry out a feasible law about fire protection management of the old building remedy to make the management work "with law, by law, under law with no exception". The law about the fire protection of old building remedy should be perfected as soon as possible to promote the process of legalized management. Moreover, effective rules and regulations should be established to make fire protection management reasonable and justified, achieving self-prevention and self-rescue as possible.

\section{CONCLUSIONS}

The management work of fire fighting and security of the old building remedy should be led by the government with the active cooperation and independent work of function departments such as the fire, cultural relics, culture, religion, tourist, garden and urban development. All levels of organizations and units should carry out responsibilities assigned by the fire protection law seriously, conduct corresponding fire modification feasibly, eliminate and regulate existing fire risk, and establish standard fire protection environment gradually. With the increase input of money and the strengthened fire protection management of ancient architecture, the fire protection design for ancient architecture and city fire protection planning should be complied reasonably to establish and perfect fire fighting facilities according to the urban environment. Moreover, the perfection of law construction about the old building remedy can promote the process of legalized management. In a word, the fire protection work of the old building remedy should be guided by scientific development view to ensure the safety of Chinese old building remedy.

\section{REFERENCES}

[1] Fire Control Bureau of Public Security Ministry. Fire Fighting \& Rescue[M], Chinese People's Public Security University Press, 2002

[2] Li Caiqin, Wang Mingzhen. Chinese Ancient Architecture and Fire [M],Shanghai Scientific \& Technical Publishers, 2009.

[3] The Political Department of Public Security Ministry. Fire Application tactics[M], Chinese People's Public Security University Publishers, 1998.

[4] Chinese Team Construction of Fire Association and Fire Speciality Committee.Fire Manual[M], Shanghai Scientific \& Technical Press, 1998.

[5] Liu Jianghong, Liao Guangxuan and Fan Weicheng, etc. Introduction of Water Mist Fire Suppression Technique[J], Fire Safety Science, 2001, 10(1): 34-37.

[6] Ruan Yisan, Wang Jinghui. Conservation, Theory and Planning of the Conservation of the Historical and Cultural Cities [M],Tongji University Press, 2002.

[7] Guo Zhiyuan. Disscussion on Fire-fighting Safety Countermeasures of Ancient Architecture. Shanxi Architecture[J], $2015,8,41(24): 250 \sim 251$

[8] Fire safety Characteristics and Countermeasuer of the Ancient Architecture. Low carbon world[J], 2015, 7: 264 265.

[9] Su Weiping, Guo Hang. The Fire Control Safety Measures of consideration and Suggestion of Ancient Buildings. City Buildings[J], 2014, 24:238

[10] Research and Analysis of the Fire Prevention Countermeasuers and Fire safety Characteristics of Ancient Buidings. City Buildings[J], 2014, 23:166 